\title{
Technomass and cooling demand in South America: a superlinear relationship?
}

\author{
Authors: \\ Massimo Palme, Luis Inostroza \& Agnese Salvati
}

This is the final author version of the article published by:

\section{Building Research \& Information}

ISSN: 0961-3218 (Print) 1466-4321 (Online)

To cite this article:

Massimo Palme, Luis Inostroza \& Agnese Salvati (2018) Technomass and cooling demand in South America: a superlinear relationship?, Building Research \& Information, 46:8, 864-880, DOI: 10.1080/09613218.2018.1483868 


\section{Introduction}

The complementary influences of urban climate and urban morphology have been largely investigated according to complementary approaches: (1), searching for the influence of the built environment on climate, for example, urban heat island (UHI) studies (Akbari et al., 2016; Kolokotroni, Zhang, \& Watkins, 2007; Oke, $1973,1982,1988$; Santamouris, 2007), and (2), analysing the impact of urban microclimate on buildings' energy consumption and thermal comfort (Kolokotroni, Ren, Davies, \& Mavrogianni, 2012; Ratti, Baker, \& Steemers, 2005; Sailor, 2014; Salvati, Coch, \& Cecere, 2017). The temperature increase is not uniform across an urban area, being mostly dependent on the building density (Bueno, Roth, Norford, \& Li, 2014; Nakano, Bueno, Norford, \& Reinhart, 2015; Palme, Lobato \& Carrasco, 2016; Palme, Inostroza, Villacreses, Lobato \& Carrasco, 2017, Allegrini, Dorer, \& Carmeliet, 2015). The global energy penalty (GEP) is a technique (Santamouris 2014a, 2014b) to estimate the impact of urban climate on the energy consumption of buildings and involves energy simulations of representative building types using urban and rural climatic data. However, methodologies for the selection of representative building types and for modelling energy consumptions at the district scale are still under development. Research on the relationships among land use, building density and sustainability of urban environments highlights that compact, high-density cities are better compared to sprawling automobile-based cities because of the more efficient use of resources, reduced costs for transportation, and reduced risk of social segregation via mixed land use (Hui, 2001; Mills et al., 2010; Morganti et al., 2017; Ng, 2010; Williams et al., 2000). However, an increase in building density can be achieved in different ways: increasing building depth, increasing building height, or increasing the compactness of urban textures (Steemers, 2003). Therefore, densification may lead to very different urban forms and building types, which, in turn, can modify the energy and environmental performance of buildings at the urban scale (Berghauser Pont and Haupt, 2007; March and Martin, 1972; Ratti et al., 2005, 2003). Further research on the impact of the morphological variety in the urban tissue - both in the horizontal and the vertical dimension - on the urban climate and buildings' energy demand is required.

An increasing number of studies are focused instead on the metabolism of cities, assessing the fluxes of energy, matter and information (Kennedy, Pincetl, \& Bunje, 2011; Kennedy, Cuddihy, \& Engel-Yan, 2007; Mindali, Raveh, \& Salomon, 2004; Zhang et al., 2012; Zhang, 2013) However, only a few of these studies included urban form analysis in the assessment of the urban metabolism, despite the strong connection between the urban fluxes and the material structure of the urban environment (Inostroza, 2014). The technomass (TM) indicator (Inostroza, 2014) has been proposed to overcome this limitation by accounting for the material accumulation of anthropogenic matter per unit of surface. This approach links urban form and metabolism, where the reciprocal influences of morphology and function are producing strong heat dissipation path dependencies (Inostroza, 2018). TM is a spatially explicit 3D indicator particularly suitable for urban climate analysis, considering the key role of urban form in determining the UHI intensity (Oke \& Stewart, 2012; Palme, Lobato \& Carrasco., 2016; Rodríguez-Álvarez, 2013; Salvati, Palme \& Inostroza, 2017). Linking urban form analysis with climate modelling would allow for a robust assessment of the environmental impact of urban development, considering the interdependencies among TM increase, UHI and the total energy requirements for buildings. This is a core topic for South American cities, considering the high rate of urban expansion (Cohen, 2006) and the observed reduction in density patterns that this expansion generates (Inostroza et al., 2013). The overlapping effect of the UHI intensity is detrimental to the building energy performance, especially in large cities located in hot climates (Santamouris \& Kolokotsa, 2016) Moreover, in South America, a change in comfort expectations will probably produce an increase in the energy demand for space cooling in buildings. As highlighted in previous studies (Brager and de Dear, 2008), the increase of comfort expectations is mainly linked to the increase of the average per capita income and the efficiency of systems and machines designed to accomplish the challenge. In the future, air conditioning is supposed to increase by $500 \%$ at the world level, basically due to changes in the living conditions of China and India (Santamouris \& Kolokotsa, 2016). South America will contribute to this trend, being the continent with the highest rate of urban growth (Cohen, 2006).

The urban climate and the influence of urban form on buildings' consumption has been studied in recent years in the South American context, with a primary focus on cities in Brazil, Argentina and Chile (Figuerola 
\& Mazzeo, 1998; Romero, Irarrázaval, Opazo, Salgado, \& Smith, 2010; Sarricolea \& Romero, 2010; Sobral, 2005, Correa, Ruiz, Canton, \& Lesino, 2012; Palme, Inostroza, Villacreses, Lobato \& Carrasco, 2017a; Sosa, Correa, \& Canton, 2017). However, a clear connection between the built-up mass and the energy consumption has not been explored yet. Changes in form and building density can thus affect both climate and the energy consumption of buildings. The increase of the built density and the consequent heat generated by heating, ventilation and air conditioning (HVAC) systems and by traffic may determine a UHI intensity increase (Salvati, Coch Roura, \& Cecere, 2016). Such a UHI intensity increase may entail an increase of the buildings' cooling loads and a reduction of the heating loads (Salvati, Coch, \& Morganti, 2017). Therefore, changes in urban morphology can determine a variation of the energy performance of buildings through primary and secondary effects: an increase of building mass causes an inevitable rise of global energy demand (first order), and less obvious, a morphological change in urban developments can increase the UHI intensity, significantly impacting the final energy demand (second order). This study shows that the combination of these effects may lead to a superlinear relationship between buildings' cooling demand and TM, i.e., energy demand may grow faster than the increase of TM. Based on the results across the urban fabric of four South American cities, the less energy efficient urban patterns have been identified. Some possible implications for urban planning and building design, such as better façade design, have been suggested to mitigate the adverse effect of uncontrolled density increase.

\section{Methods}

The relationship between buildings' cooling demand and built density has been explored by applying multiscale analyses that include four steps: (1) identification of the representative samples of the urban fabric in four South American cities; (2) calculation of the TM of each urban sample; (3) classification of the samples into urban tissue categories (UTC) for estimation of the UHI intensity; and (4) simulation of the total cooling energy demand of all the buildings within each sample and evaluation of the energy penalty determined by the urban context. The UHI intensity is calculated using the Urban Weather Generator (UWG), a coupled atmosphere-building simulator developed to generate urban weather files for building energy modelling using meteorological information from the cities' reference weather stations (i.e., the typical meteorological year) and parameters of urban area as inputs (Bueno et al., 2013). The building performance simulations are performed using TRNSYS $\subset$ software, considering different model setups and weather files for rural and urban contexts, which allows for evaluation of the 'global energy penalty' determined by urban contexts.

\section{Case studies: Antofagasta, Valparaiso, Guayaquil and Lima}

Four South American coastal cities are used as case studies: Antofagasta and Valparaiso in Chile, Guayaquil in Ecuador and Lima in Peru. These four cities have different sizes, latitudes and urban morphologies, allowing for exploration of the variability of the relationship between urban form and building energy demand in different climatic and urban contexts (Table 1). In the hottest months of the year, the global horizontal solar radiation and diurnal temperature range are maximum in Valparaiso and minimum in Guayaquil because Valparaiso and Guayaquil are the cities with the highest and lowest latitudes, respectively, among the four (Figure 1). The average daily air temperature is higher in Guayaquil and Lima compared to Antofagasta and Valparaiso.

\section{Urban tissue categories (UTC) for UHI evaluation}

The UTC methodology is designed to group random samples of urban tissue of an urban area into groups with similar urban morphology for urban microclimate analysis. The UTC classification can be used to relate the existing morphology variability of a city to the estimated temperature variability across it; thus, the UTC classification is used to conduct building performance simulation in the urban context (Palme, Inostroza, Villacreses, Lobato and Carrasco, 2017 a and b). We developed our analysis on the basis of a successfully tested sample of 24 urban tissues of 1 hectare in the four cities that is fully available in (Palme, Inostroza, Villacreses, Lobato and Carrasco, $2017 \mathrm{a}$ and b). The distribution of the samples is shown in Figure 2. Each sample is parameterised using three key variables of urban morphology that have major impacts on the UHI intensity at the local scale and that can be calculated from GIS data. The three variables are as follows: 1) Site 
coverage ratio (SCR), which is the ratio of the building footprints to the site area, 2) Façade-to-site ratio (FSR), which is the ratio of the vertical surface area (facades) to the site area, and 3) Vegetation coverage ratio (VCR), which is the ratio of the green area to the site area.

Principal component analysis (PCA) is used to group the convergence of the variance of the three variables into a set of uncorrelated linear components. PCA allows further mathematical manipulation, thus avoiding the endogeneity of the original variables. Varimax orthogonal rotation was applied to enhance the convergence of similar values, and the Kaiser rule was used for the retention of components (Abdi \& Williams, 2010; Abdi, 2003). The rotated values of each sample factor score are plotted on the PCA biplot graph and used for dimensionality reduction to select the two most representative variables among the three uncorrelated dimensions. The retained components express these two uncorrelated dimensions of urban form for each city: SCR and FSR. UTC values are then identified as clusters of samples on the plot, where proximity implies sharing such morphological properties. For classifying the urban samples into groups with similar UHI intensity, the variations of the SCR and the FSR are much more significant than the variation of the VCR. This has been highlighted in studies focused on the Mediterranean context (Salvati, Palme, \& Inostroza, 2017) as well as in validation studies of the UWG model in different geographical contexts (Bueno, Roth, Norford, \& Li, 2014; Nakano, Bueno, Norford, \& Reinhart, 2015; Palme, Inostroza, Villacreses, Lobato and Carrasco, $2017 \mathrm{a}$ and b). At the same time, the clustering of UTCs is more straightforward in a bidimensional plane than in a tri-dimensional space.

The procedure for the UTC classification is depicted in figure 3 . For each UTC, the corresponding UHI intensity is calculated using the UWG model. UWG estimates the canopy level air temperature of a homogeneous urban area based on the values of the SCR, the FSR, the average building height, and other parameters. The model has been validated in Boston (Street, Reinhart, Norford, \& Ochsendorf, 2013), Toulouse in France and Basel in Switzerland (Bueno, Norford, Hidalgo, \& Pigeon, 2013), Singapore (Bueno, Roth, Norford, \& Li, 2014), Abu Dhabi (Mao, Yang, Afshari, \& Norford, 2017) and Rome and Barcelona (Salvati, Coch, \& Cecere, 2016), resulting in sufficient accuracy to predict the UHI intensity at the neighbourhood scale to perform building performance studies.

\section{Technomass estimation: Mass and volume computation}

The TM estimation is based on calculations of the parametric weights of four reference housing typologies (Figure 3 ) identified across the built environment of the studied cities: detached or semi-detached houses (2 floors), terraced houses (2-3 floors), apartment blocks (4-8 floors) and tall buildings (more than 8 floors). These categories follow the definitions provided by the TABULA project for European building typologies (Loga, Diefenbach, Dascalaki, \& Balaras, 2010).

The total volume of each housing type in the samples $\left(V t_{i}\right)$ was derived from GIS data, including the available data of the built-up area as well as the perimeter and height of all the buildings in the samples. The weight per unit volume of each housing type, $M t_{i}\left(\mathrm{Tons} / \mathrm{m}^{3}\right)$, was calculated using one reference building for each category (Figure 4) and considering the following components: vertical structure, slabs, roof, external walls and windows, internal partitions and doors, and stairs and lifts. Only above ground TM was calculated to obtain comparable results; thus, the weight of the underground structures was omitted. Building systems were also considered using default parametric values from the literature (Morganti, Pages, Isalgue, Coch, \& Cecere, 2012). The weight of the housing type per unit volume was obtained as the ratio of the total weight of the reference building (given by the sum of the weights of all the components) to the whole building volume.

The TM of the urban samples is obtained as the sum of the products of the parametric weights $\left(\mathrm{Tons} / \mathrm{m}^{3}\right)$ of the different housing types and the total volume of the buildings of each type in the sample, as expressed in Equation 1: 


$$
\mathrm{Ms}=\Sigma\left(M t_{i} x V t_{i}\right)
$$

where Ms is the TM of the sample in Tons/hectare, $M t_{i}$ is the weight per unit volume $\left(\right.$ Tons $\left./ \mathrm{m}^{3}\right)$ of each housing type $\left(t_{i}\right)$, and $\left.V t_{i}\right)$ is the total volume of each housing type in the sample.

\section{Energy demand and energy penalty}

To estimate the energy performance of the 24 samples in each city, building performance simulation (BPS) was conducted for the four residential building types. BPS was conducted using TRNSYS @ tool version 17 following the steps depicted in Figure 5. The total cooling load of each sample was calculated using volumes instead of surfaces by multiplying the cooling demand per cubic metre of each housing type by the effective volume of each type in the sample. The global energy penalty was obtained by comparing the BPS result corresponding to a rural environment (including standard weather data, no shadows and no radiant exchange between buildings) to those in urban environments using urban weather files, building shadows and radiant exchange between buildings. The results for the hottest months of the year (from January to March) are presented and analysed. The main variables of the model setup for the BPS are reported in Table 2. The cooling load of the housing types in the urban context was calculated for all the different boundary conditions determined by the morphology of the UTCs, namely, average UHI intensity, shortwave radiation obstruction (shadows) and long-wave radiation exchange between buildings. Details on the procedure are described in the Appendix.

\section{Results}

\section{Housing types and technomass in the urban samples}

Figure 6 shows the variability of the TM and the percentage of housing types present in the 24 samples in the four cities. Detached and terraced house are the predominant types. In Guayaquil, these two types represent almost the entire housing stock analysed. The urban morphology of Guayaquil is homogenous and composed of a low building density, with an average building height of only two floors, resulting in the low value of the average TM $\left(8,260\right.$ Ton $^{*}$ ha $\left.^{-1}\right)$ and the small standard deviation $\left(3,980\right.$ Ton $^{*}$ ha $\left.^{-1}\right)$. The urban morphology in Lima is also homogeneous, where, in addition to detached and terraced houses, apartment blocks are also common. The average TM and the standard deviation are slightly higher than those in Guayaquil (12,590 and 5,880 Ton*ha ${ }^{-1}$, respectively). Conversely, Antofagasta and Valparaiso show a higher variability of TM because of the presence of all four housing types in similar proportions. The average TM is equal to 13,350 Ton*ha ${ }^{-1}$ in Antofagasta and 15,330 Ton*ha ${ }^{-1}$ in Valparaiso, indicating higher average building density in comparison to those in Lima and Guayaquil. The standard deviation of TM is also higher: 12,710 Ton*ha ${ }^{-1}$ for Antofagasta and 12,070 Ton*ha ${ }^{-1}$ for Valparaiso.

\section{Urban tissue categories (UTCs)}

Two components were retained in all cases, reflecting the variability of the SCR and the FSR among the 24 urban samples of each city. The relative position of each point on the graph indicates particular morphological characteristics of the urban sample: top-right quadrant - high SCR and high FSR; bottom-right quadrant - high SCR and low FSR; bottom-left quadrant - low SCR and low FSR; and top-left quadrant - low SCR and high FSR. The UTCs for each city have been identified as a cluster of samples on the bi-plots, as represented in Figure 7. The average values of the original morphological parameters for each cluster of samples - i.e., for each UTC - are reported in Table 3; these parameters have been used to estimate the corresponding UHI intensity in the UWG model. The number and morphological characteristics of the UTCs are particular to each city, being based on the morphological variability of the 24 urban tissue random samples. For this reason, clusters of samples of different cities may have rather different morphological characteristics, even if they are located in the same relative position on the bi-plots graphs. Moreover, the values of the morphological parameters for the denser UTC (clusters in the top-right quarter) and the less dense UTC (clusters in the bottom-left quarter) vary significantly among different cities (i.e., the denser UTC of Antofagasta - UTC1 - has a SCR equal 
to 0.76 , a FSR equal to 1.65 and a building height equal to $11.33 \mathrm{~m}$, whereas the denser UTC in Lima has a SCR equal to 0.72 , a FSR equal to 1.34 and a building height equal to $7.72 \mathrm{~m}$ ).

\section{UTC and urban heat island intensity for each city}

Figure 8 shows the results of UHI calculations performed with UWG for each city and UTC. The daily average $\mathrm{UHI}$ intensity is significant in the four cities. The maximum nocturnal UHI intensity is found in Valparaiso $\left(4.3^{\circ} \mathrm{C}\right.$, Table 4). In Antofagasta and Guayaquil, the nocturnal average intensity in summer reaches more than $2^{\circ} \mathrm{C}$ in the densest UTC (UTC1), whereas in Lima, the daily UHI intensity is always below $1^{\circ} \mathrm{C}$ during both daytime and night-time. These results are in line with available monitoring data (Serricolea \& Romero 2016; Carrasco et al. 2017, Palme et al. 2016). The impact of urban morphology on UHI intensity is different in the four cities. Valparaiso and Antofagasta show a higher variability of the UHI intensity for the different UTCs compared to Guayaquil and Lima. In Valparaiso, the UHI intensity between different UTCs varies between 4.3 ${ }^{\circ} \mathrm{C}$ and $2.6^{\circ} \mathrm{C}$ during the night-time. In Antofagasta, the maximum difference of UHI intensity is between 2.0 ${ }^{\circ} \mathrm{C}$ and $1.3^{\circ} \mathrm{C}$. The $\mathrm{UHI}$ intensity in Lima and Guayaquil is instead quite homogeneous, with temperature variation below $0.5{ }^{\circ} \mathrm{C}$ among the different UTCs. This different behaviour can be explained by two factors: (1) the homogeneity of the urban form across the city and (2) the climate and latitude of the cities. The results of the TM estimations showed that Valparaiso and Antofagasta are characterized by a higher variability in urban morphology than Guayaquil and Lima because of the different distributions of the building types. Furthermore, in Valparaiso and Antofagasta, the UTCs with the maximum values of site coverage ratio and façade-to-site ratio were found, often corresponding to a high value of the average building height (see Table 3, UTCs 1 and 3 for Antofagasta and UTCs 1 and 3 for Valparaiso): for these UTCs, UWG estimated the maximum UHI intensity among all the case studies, resulting in a greater range of variability of urban temperature for the two cities. Regarding the climate, Guayaquil and Lima have a higher average temperature and a smaller diurnal temperature range than do Antofagasta and Valparaiso; these differences contribute to mitigating the temperature differences between the urban and rural contexts. The four cities are also located at different latitudes; this difference in latitude plays an important role in the influence of urban morphology on the UHI intensity. Lima and Guayaquil are located close to the equator and have high solar altitudes that probably reduce the possibility of interaction with the canyon geometry, whereas in Antofagasta and Valparaiso, the lower solar altitudes may determine multiple reflections within the canyon surfaces and increase the heat storage. Alternatively, at mid-latitudes, such as in Valparaiso, the urban geometry can also determine the so-called cool island during the daytime, namely, a reduction of urban temperature compared to the rural one during the hottest hours of the day caused by the beneficial effect of shadow (Figure 8). This beneficial effect is, however, counterbalanced by a higher nocturnal UHI intensity because of the impact of urban geometry on infrared radiation heat loss.

\section{BPS results: energy demand and energy penalty}

The analysis of BPS results is divided into three parts. First, the cooling loads of each housing type are analysed for each city and UTC. Second, the global energy penalty for each city and sample is presented. Third, the relationship between energy demand and energy penalty is discussed. BPS results for the four housing types (Table 5) showed a general increase of the cooling demand in the urban context compared to the rural ones. However, note that in some cases, the cooling load also decreased in the urban context because of the specific combinations of increased shadows, radiant exchange modifications and UHI intensity. This was the case of the detached houses and terraced houses in the UTC1 and UTC2 of Lima and of the apartment blocks, terraced houses and detached houses in the UTC1 and UTC3 of Antofagasta. These UTCs correspond to dense environments, where both the site coverage ratio and the façade-to-site ratio values are high, i.e., the buildings are close and rather tall. For such textures, the shadows determined by the urban context have a significant impact on the building energy demand, especially on low-rise buildings. The reference climate of the four cities also influenced the results. In Guayaquil and Valparaiso, with similar dense urban contexts in terms of site coverage ratio and façade-to-site ratio, a reduction of the cooling demand was not determined for any building type. Therefore, the results suggest that in desert climates, solar radiation can be regarded as a more important parameter with respect to the environmental temperature, whereas in tropical (Guayaquil) and Mediterranean (Valparaiso) climates, the environmental temperature plays a fundamental role in the final cooling demand, being comparable to the incoming radiation. Figure 9 , 
Figure 10, Figure 11 and Figure 12 report the cooling energy demand results for the four cities as a function of the TM of the 24 samples, comparing the loads obtained while considering the rural and urban environments in the BPS. The difference between the trend lines for rural and urban results is the graphical representation of the energy penalty determined by the urban context. The graphs clearly show that the energy penalty is not constant across the urban area but varies significantly with the TM of the samples (Figure 13). The maximum variability is found in Antofagasta and Valparaiso, where the penalty varies between 0 and $300 \mathrm{kWh} / \mathrm{ha}$. Lima and Guayaquil have a more uniform behaviour because of the reduced morphological differences among the samples. There are cases in Lima and Antofagasta where the cooling penalty per hectare is negative as a result of the shadows' influence. This negative penalty is found for UTCs with high UHI intensity.

\section{Technomass and energy demand}

Different cooling penalties introduced by UHI lead to differences in the total cooling demand of each sample. In all cases, the cooling demand increases with TM; however, the slope of the increase varies and is important. We used in Figure 14 a double logarithmic scale (base 2 ) to explore these variations, where if the $x$ value is doubled and the $y$ value is doubled as a response (gradient 1 in the line), then the relation is defined as linear. Therefore, if the gradient is less than 1 , then the relation is sublinear, whereas if the gradient is greater than 1, then it is superlinear. This definition is very important to establish because a sublinear behaviour indicates an increase in thermal efficiency with TM, whereas a superlinear behaviour indicates a decrease in efficiency. The results of BPS showed a clear superlinear relationship between the cooling demand and the TM increase in Antofagasta (gradient 1.64) and Valparaiso (1.20), whereas the trends for Lima (0.92) and Guayaquil (0.88) were found to be slightly sublinear. The different trends is due to the smaller variability of the TM in Lima and Guayaquil (5 to $20 \mathrm{kTon}^{*} \mathrm{ha}^{-1}$ ) compared to that in Valparaiso and Antofagasta ( 5 to $60 \mathrm{kTon}^{*} \mathrm{ha}^{-1}$ ); low values of the TM in fact entail a lower average UHI intensity and the absence of tall buildings across the urban area (tall buildings correspond to an increase of cooling loads, being the housing typology with the highest cooling demand, regardless of the context).

\section{Discussion}

The UTC classification is a novel proven approach to classify the urban morphology of a city in a manner particularly suited for urban climate analysis (Palme et al 2017, Martilli 2014). The relationships between cooling energy demand and the TM of the urban samples suggest the existence of a critical mass that might generate a transition in the urban cooling consumptions from linear to superlinear. The transition might be caused by the detrimental impact of the UHI effect and the infrared environment in dense urban environments. This is in line with previous studies that identified some threshold values of the site coverage ratio and the façade-to-site ratio, beyond which the UHI intensity becomes significant in the Mediterranean climates (Salvati, 2016). According to the results, it appears that the increase in building density obtained by vertical growth could generate the superlinear transition of the cooling energy consumptions (Figure 9 and Figure 10 ). The increase of building height determines an increase of the façade-to-site ratio of the urban area, which in turn plays an important role in the UHI intensity (Salvati, 2016). Tall buildings have the highest cooling loads, regardless of the context, being characterized by a higher ratio of transparent surfaces and less exposed surfaces compared to the other typologies. The standard design of high-rise buildings reduces heat dissipation during both winter and summer seasons. This is a positive effect in winter and across the entire year in cold environments. However, in South American climates, high-rise buildings have a strong negative impact on the cooling demand, as shown by the BPS results. There is a critical TM value above, which a superlinear transition in the energy consumption occurs. In the analysed cities, the critical mass transition threshold was found to be between 25,000 and 30,000 ton*ha ${ }^{-1}$, achieved with vertical growth, causing an unavoidable shift in the cooling demand. This threshold must be further tested in other cities and latitudes to explore differences and similarities. The relationship between TM and cooling demand increase can inform policymaking, especially for the development of parametric normative rules for urban planning to control unregulated urban energy consumption increases. Once the structural layout of the urban morphology is established regarding green areas, streets and other public spaces needed per hectare, the maximum volume 
of TM that is possible to build up while avoiding the superlinear transition of energy consumptions can be evaluated.

\section{Strengths and limitations of the study}

This study provides quantitative evidence to foster climatically sensitive urban planning, considering both urban building energy consumption and urban form. However, our method has four limitations. First, it is based only on the hottest period of the year, from January to March. This approach was taken because of the presence of cooling needs only during this period in three of the four study cases. Only Guayaquil has cooling needs during the whole year. A whole year building performance simulation including heating demand estimations is required to assess the annual energy balance. The results for the heating season would probably affect the global results for the case of Valparaíso, where the winter season is rather cold. Conversely, in the other three cities (Guayaquil, Lima and Antofagasta), the heating demand is normally null or negligible. Second, the anthropogenic heat generated by traffic, an important variable of the UHI generation, has been considered a fixed value in all the simulations of the UHI intensity. In future research, information on the particular patterns of traffic across the urban areas will be considered to improve the accuracy of the climate and energy estimations. The third limitation of the study is that the BPS assumed the ground surface temperature to be the temperature of the entire infrared environment, leading to the approximation that the long wave interchange is equal to zero. A more accurate estimation would determine the uniform temperature representative of the environment as the weighted (by view factors) average temperature of all surfaces of the radiant environment. However, in the absence of uncommon surfaces (e.g., solar absorbers, solar reflectors, or low emission materials), this simplification may entail a maximum error of $10 \%$ in the infrared radiation exchange. In the ground surface temperature calculation, airspeed is also assumed to be zero, reducing the convection loss coefficient and consequently increasing the surface temperature. This approximation is reliable if the urban canyon aspect ratio (building height to street width) is greater than 1, as is the case for most of the analysed UTCs. However, future research should involve the analysis of special urban situations in which air circulation can affect both the outdoor microclimate and the indoor natural ventilation. The consideration of only residential buildings in the analysis is the fourth limitation. Future work will consider other building types with higher levels of internal heat gains and more accurate environmental control, e.g., commercial buildings, institutional buildings, schools and hospitals.

\section{Conclusion}

The results of this research provide evidence on the double nexus existing between UHI and urban morphology. The built environment generates different UHI intensities and other changes in the microclimate that can vary according to particular TM thresholds. The specific site conditions generate differences in the cooling needs. The simulation results showed that higher levels of UHI are expected in regions where higher amounts of $\mathrm{TM}$ are concentrated, especially if vertical development is present. The increase of cooling needs in fact depends on building density and vertical development. However, the combination of different effects in urban environments, such as UHI intensity and direct radiation reduction, causes a more dispersed situation in the site-specific results. Vertical development appears to have a greater influence than building density on the cooling needs of specific sites because of the change in the building type. Vertical growth is achieved by using constructive systems with more transparency on the facades, less shadows from the urban context, and less heat losses thorough the building envelope. The relationship between cooling demand and TM is linear until a critical value of mass is reached. The threshold is approximately 25,000-30,000 Ton*he ${ }^{-1}$. Once this value is exceeded, the cooling demand shows a superlinear behaviour caused by the UHI increase in dense and high sectors of the city and the changes in the building type that affect its energetic behaviour. Our research links urban climate analysis to BPS at the urban scale, providing empirical evidence of the changing influence of urban form on energy demand. These findings are relevant to the development of climate-informed urban planning.

\section{References}


Abdi, H., 2003. Factor Rotations in Factor Analyses. Encycl. Soc. Sci. Res. 1-8. doi:10.4135/9781412950589.n873

Abdi, H., Williams, L.J., 2010. Principal component analysis - Abdi - 2010 - Wiley Interdisciplinary Reviews: Computational Statistics - Wiley Online Library. Wiley Interdiscip. Rev. ....

Akbari, H., Cartalis, C., Kolokotsa, D., Muscio, A., Pisello, A.L., Rossi, F., Santamouris, M., Synnefa, A., Wong, N.H., Zinzi, M., 2016. Local climate change and urban heat island mitigation techniques - the state of the art. J. Civ. Eng. Manag. 22, 1-16. doi:10.3846/13923730.2015.1111934

ASHRAE, 2009. ASHRAE Handbook-Fundamentals. ASHRAE Handbook-Fundamentals 21.1-21.67. doi:10.1017/CBO9781107415324.004

Berghauser Pont, M.Y., Haupt, P.A., 2007. The relation between urban form and density. Urban Morphol.

Brager, G.S., de Dear, R.J., 2008. Historical and Cultural Influences on Comfort Expectations, in: Buildings, Culture and Environment: Informing Local and Global Practices. pp. 177-201. doi:10.1002/9780470759066.ch11

Bueno, B., Norford, L., Hidalgo, J., Pigeon, G., 2013. The urban weather generator. J. Build. Perform. Simul. 6, 269-281. doi:10.1080/19401493.2012.718797

Bueno, B., Norford, L., Pigeon, G., Britter, R., 2011. Combining a Detailed Building Energy Model with a Physically-Based Urban Canopy Model. Boundary-Layer Meteorol. 140, 471-489. doi:10.1007/s10546011-9620-6

Bueno, B., Roth, M., Norford, L., Li, R., 2014. Computationally efficient prediction of canopy level urban air temperature at the neighbourhood scale. Urban Clim. 9, 35-53. doi:10.1016/j.uclim.2014.05.005

Cohen, B., 2006. Urbanization in developing countries: Current trends, future projections, and key challenges for sustainability. Technol. Soc. doi:10.1016/j.techsoc.2005.10.005

Figuerola, P.I., Mazzeo, N.A., 1998. Urban-rural temperature differences in Buenos Aires. Int. J. Climatol. 18, 1709-1723. doi:10.1002/(SICI)1097-0088(199812)18:15<1709::AID-JOC338>3.0.CO;2-I

Hui, S.C.M., 2001. Low energy building design in high density urban cities. Renew. Energy 24, 627-640. doi:http://dx.doi.org/10.1016/S0960-1481(01)00049-0

Inostroza, L., 2018. The circularity of the urban ecosystem material productivity: The transformation of biomass into technomass in Southern Patagonia. Sustain. Cities Soc. 39. doi:10.1016/j.scs.2018.03.001

Inostroza, L., 2014. Measuring urban ecosystem functions through "Technomass" - A novel indicator to assess urban metabolism. Ecol. Indic. 42, 10-19. doi:http://dx.doi.org/10.1016/j.ecolind.2014.02.035

Inostroza, L., Baur, R., Csaplovics, E., 2013. Urban sprawl and fragmentation in Latin America : A dynamic quantification and characterization of spatial patterns. J. Environ. Manage. 115, 87-97.

Kennedy, C., Cuddihy, J., Engel-Yan, J., 2007. The Changing Metabolism of Cities. J. Ind. Ecol. 11, 43-59. doi:10.1162/jie.2007.1107

Kennedy, C., Pincetl, S., Bunje, P., 2011. The study of urban metabolism and its applications to urban planning and design. Environ. Pollut. doi:10.1016/j.envpol.2010.10.022

Kolokotroni, M., Ren, X., Davies, M., Mavrogianni, A., 2012. London's urban heat island: Impact on current and future energy consumption in office buildings. Energy Build. 47, 302-311. doi:10.1016/j.enbuild.2011.12.019

Kolokotroni, M., Zhang, Y., Watkins, R., 2007. The London Heat Island and building cooling design. Sol. Energy 81, 102-110. doi:10.1016/j.solener.2006.06.005

March, L., Martin, L., 1972. Urban Space and Structures. University Press, Cambridge, UK.

Masson, V., 2000. A physically-based scheme for the urban energy budget in atmospheric models. Boundary-layer Meteorol. 94, 357-397. doi:10.1023/A:1002463829265

Mills, G., Cleugh, H., Emmanuel, R., Endlicher, W., Erell, E., McGranahan, G., Ng, E., Nickson, A., Rosenthal, J., Steemers, K., 2010. Climate Information for Improved Planning and Management of Mega Cities (Needs Perspective). Procedia Environ. Sci. 1, 228-246. doi:10.1016/j.proenv.2010.09.015

Mindali, O., Raveh, A., Salomon, I., 2004. Urban density and energy consumption: A new look at old statistics. Transp. Res. Part A Policy Pract. 38, 143-162. doi:10.1016/j.tra.2003.10.004

Morganti, M., Pages-ramon, A., Isalgue, A., Coch, H., Cecere, C., 2012. Built-Form , Mass and Energy Urban fabric performance. 
Morganti, M., Salvati, A., Coch, H., Cecere, C., 2017. Urban morphology indicators for solar energy analysis. Energy Procedia 134C, 807-814.

Nakano, A., Bueno, B., Norford, L., Reinhart, C.F., 2015. URBAN WEATHER GENERATOR - A NOVEL WORKFLOW FOR INTEGRATING URBAN HEAT ISLAND EFFECT WITHIN URBAN DESIGN PROCESS Massachusetts Institute of Technology , Cambridge , USA Fraunhofer Institute for Solar Energy Systems ISE , Germany SIMULATION ENGINE \& PLATFOR. Build. Simul. Conf. 1901-1908.

Ng, E., 2010. Designing High-Density Cities: For Social \& Environmental Sustainability, in Designing highdensity cities for social and environmental sustainability, E. Ng, Ed., ed London: Earthscan, 2010, pp. doi:10.1080/07293682.2011.530590

O'Callaghan, P.W., Probert, S.D., 1977. Sol-air temperature. Appl. Energy 3, 307-311. doi:10.1016/03062619(77)90017-4

Oke, T.R., 1988. Street design and urban canopy layer climate. Energy Build. 11, 103-113. doi:10.1016/0378-7788(88)90026-6

Oke, T.R., 1982. The energetic basis of the urban heat island. Q. J. R. Meteorol. Soc. 108, 1-24. doi:10.1002/qj.49710845502

Oke, T.R., 1973. City size and the urban heat island. Atmos. Environ. Pergamon Pres 7, 769-779. doi:10.1016/0004-6981(73)90140-6

Oke, T.R., Stewart, I.D., 2012. LOCAL CLIMATE ZONE FOR URBAN TEMPERATURE STUDIES, in: Bulletin of the American Meteorological Society. pp. 1879-1900.

Palme, M., Carrasco, C., Lobato, A., 2016. Quantitative Analysis of Factors Contributing to Urban Heat Island Effect in South American Cities. Procedia Eng. 169, 199-206.

Ratti, C., Baker, N., Steemers, K., 2005. Energy consumption and urban texture. Energy Build. 37, 762-776. doi:10.1016/j.enbuild.2004.10.010

Ratti, C., Raydan, D., Steemers, K., 2003. Building form and environmental performance: archetypes, analysis and an arid climate. Energy Build. 35, 49-59. doi:10.1016/\$0378-7788(02)00079-8

Rodríguez-álvarez, J., 2013. Heat Island and Urban Morphology : Observations and analysis from six European cities. PLEA 2013 Sustain. Archit. a Renew. Futur.

Romero, H., Irarrázaval, F., Opazo, D., Salgado, M., Smith, P., 2010. Climas urbanos y contaminación atmosférica en santiago de chile hugo romero. Eure 36, 35-62. doi:10.4067/S025071612010000300002

Sailor, D.J., 2014. Risks of summertime extreme thermal conditions in buildings as a result of climate change and exacerbation of urban heat islands. Build. Environ. 78, 81-88. doi:10.1016/j.buildenv.2014.04.012

Salvati, A., 2016. The compact city in Mediterranean climate: Heat Island, Urban Morphology and Sustainability.

Salvati, A., Coch, H., Cecere, C., 2017a. Assessing the urban heat island and its energy impact on residential buildings in Mediterranean climate: Barcelona case study. Energy Build. 146, 38-54. doi:10.1016/j.enbuild.2017.04.025

Salvati, A., Coch, H., Morganti, M., 2017b. Effects of urban compactness on the building energy performance in Mediterranean climate. Energy Procedia 122, 499-504. doi:10.1016/j.egypro.2017.07.303

Salvati, A., Coch Roura, H., Cecere, C., 2016. Urban heat island prediction in the mediterranean context: An evaluation of the urban weather generator model | Predicción urbana de la isla de calor en el contexto mediterráneo: Una evaluación del modelo generador de tiempo urbano. Archit. City Environ. 11. doi:10.5821/ace.11.32.4836

Salvati, A., Palme, M., Inostroza, L., 2017c. Key Parameters for Urban Heat Island Assessment in A Mediterranean Context: A Sensitivity Analysis Using the Urban Weather Generator Model. IOP Conf. Ser. Mater. Sci. Eng. 245. doi:10.1088/1757-899X/245/8/082055

Santamouris, M., 2014. Cooling the cities - A review of reflective and green roof mitigation technologies to fight heat island and improve comfort in urban environments. Sol. Energy 103, 682-703. doi:10.1016/j.solener.2012.07.003

Santamouris, M., 2007. Heat island research in Europe: The state of the art. Adv. Build. Energy Res. 1, 123150. doi:10.1080/17512549.2007.9687272 
Santamouris, M., Kolokotsa, D., 2016. Urban climate mitigation techniques, Urban Climate Mitigation Techniques. doi:10.4324/9781315765839

Sarricolea, P., Romero, H., 2010. ANÁLISIS DE LOS FACTORES CONDICIONANTES SOBRE LAS TEMPERATURAS DE EMISIÓN SUPERFICIAL EN EL ÁREA METROPOLITANA DE VALPARAÍSO, CHILE. ACE Archit. City Environ. 45-66.

Sobral, H.R., 2005. Heat island in São Paulo, Brazil: Effects on health. Crit. Public Health 15, 147-156. doi:10.1080/09581590500151756

Solar Energy Laboratory University of Wisconsin-Madison, TRANSSOLAR Energietechnik GmbH, CSTB Centre Scientifique et Technique du Bâtiment, TESS - Thermal Energy Systems Specialists, 2009. Trnsys 17. A TRaNsient SYstem Simulation program. Volume 4 Mathematical Reference.

Steemers, K., 2003. Energy and the city: Density, buildings and transport, in: Energy and Buildings. pp. 3-14. doi:10.1016/S0378-7788(02)00075-0

Williams, K., Burton, E., Jenks, M., 2000. Achieving sustainable urban form, Land Use Policy.

Zhang, J., Heng, C.K., Malone-Lee, L.C., Hii, D.J.C., Janssen, P., Leung, K.S., Tan, B.K., 2012. Evaluating environmental implications of density: A comparative case study on the relationship between density, urban block typology and sky exposure. Autom. Constr. 22, 90-101. doi:10.1016/j.autcon.2011.06.011

Zhang, Y., 2013. Urban metabolism: a review of research methodologies. Environ. Pollut. 178, 463-73. doi:10.1016/j.envpol.2013.03.052

\section{Appendix}

The average shadow range on the building facades was estimated for simplified geometric models representative of the different UTCS. The geometric models were built using the morphology parameterisation used by the UWG (Bueno et al., 2013) and TEB (Masson, 2000) models, namely, a regular layout of square-plan buildings with the same height (Figure A1). The geometric relationships between the parameters of the Site coverage ratio and the Façade-to-site ratio of each UTC and the corresponding values of the side of the square-plan building (a) and the side of the square delimited by the facades of the surrounding buildings (b) were derived by Bueno (Bueno, Norford, Pigeon \& Britter, 2011).

The average shadow range was calculated on the central block of the grid, considering the obstruction angles $\alpha$ and $\beta$ on the middle point of the façade. Ten shadow environments were considered because of the negligible variations of the obstruction angles among similar UTCs (figure A2 and table A1). In each geometric model of the UTC, the vertical obstruction angle $\beta$ was calculated considering the height used for the energy models of each building type, namely, $6 \mathrm{~m}$ for the detached and terraced houses, $15 \mathrm{~m}$ for the apartment blocks and $60 \mathrm{~m}$ for the tall buildings. The BPS was conducted considering the same obstruction angles on all the façades.

The long-wave radiation exchange from the external surfaces to the atmosphere was calculated considering the effective sky temperature as a function of the ambient temperature, air humidity, cloudiness factor and local air pressure. The calculation was performed using the TRNSYS Type 69 (Solar Energy Laboratory University of Wisconsin-Madison et al., 2009).

For the rural context, the sky view factor of the building facades was set to 0.5 . For the urban context, the sky view factor (SVF) of external walls was calculated based on the same geometric models used for shadow computations (Figure A2).

The ground temperatures for rural and urban environments were calculated according to equations 1 and 2 , respectively (ASHRAE, 2009; O'Callaghan and Probert, 1977): 


$$
\begin{aligned}
& T_{\text {ground }}=T_{\text {environemnt }}+\frac{\alpha \times I_{H}-100 \times \varepsilon \times(1-C)}{9.42+3.68 \times v} \\
& T_{\text {ground }}=T_{\text {urban environment }}+0.2 \times \alpha \times I_{H} \times s v f
\end{aligned}
$$

where:

$v$ is the wind speed $(\mathrm{m} / \mathrm{s})$

$\alpha$ is the solar absorption of the ground (0-1)

$I_{H}$ is the total incoming radiation on the horizontal area $\left(\mathrm{W} / \mathrm{m}^{2}\right)$

$\varepsilon$ is the emissivity of the ground (0-1)

$C$ is the cloudiness factor $(0-1)$

svf is the sky view factor

In TRNSYS, the infrared radiation exchange between walls and the environment is considered to be uniform, i.e., all the surfaces that exchange radiation with the walls are assumed to be at the same temperature equal to the ground temperature; for this reason, the long wave interchange is assumed to be 0 in the urban case. In the rural environment, the long wave interchange is estimated to be $100 \mathrm{~W} / \mathrm{m}^{2}$, and the surface loss coefficient is approximately $20 \mathrm{~W} / \mathrm{m}^{2} \circ \mathrm{C}$, leading to a difference of $5 \circ \mathrm{C}$ between a high emissivity surface and the environment during a clear night (the temperature difference is 0 if the sky is cloudy).

In the urban environment, the absence of wind was assumed in the convective loss factor calculation; this is an acceptable assumption for urban areas with an average value of the ratio of building height to street width above 1 (Oke, 1988; Georgakis, \& Santamouris, 2006; Di Bernardino, Monti, Leuzzi, \& Querzoli, 2015). The average UHI effect was included in the BPS using the weather file generated by UWG for each UTC of each city (changes in temperature and humidity). 


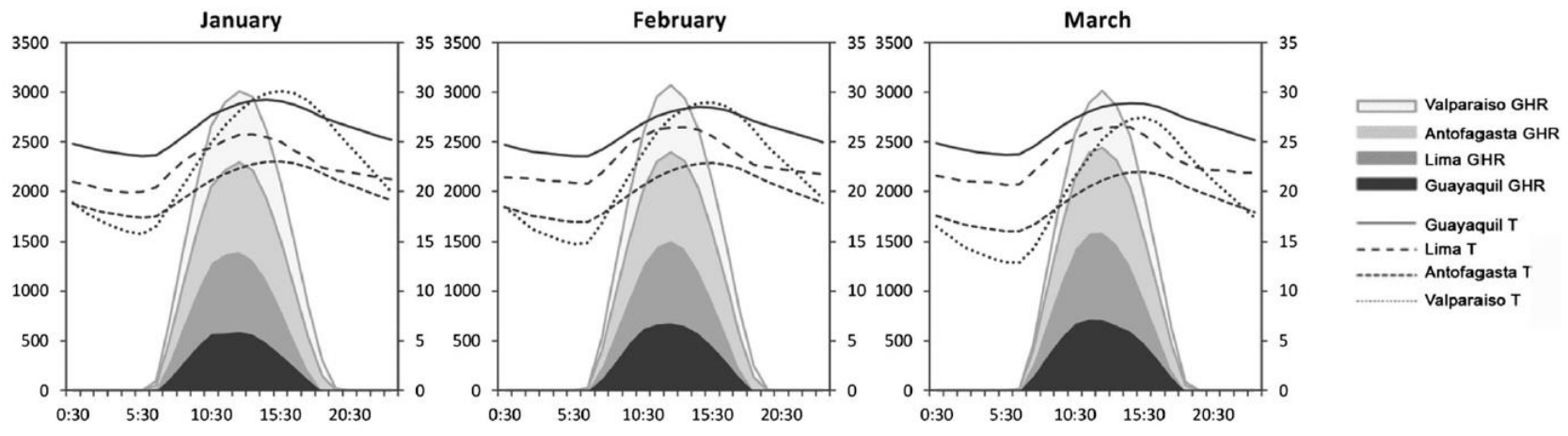

Figure 1: Diurnal cycle of air temperature and global horizontal radiation during summer months in the four cities. 

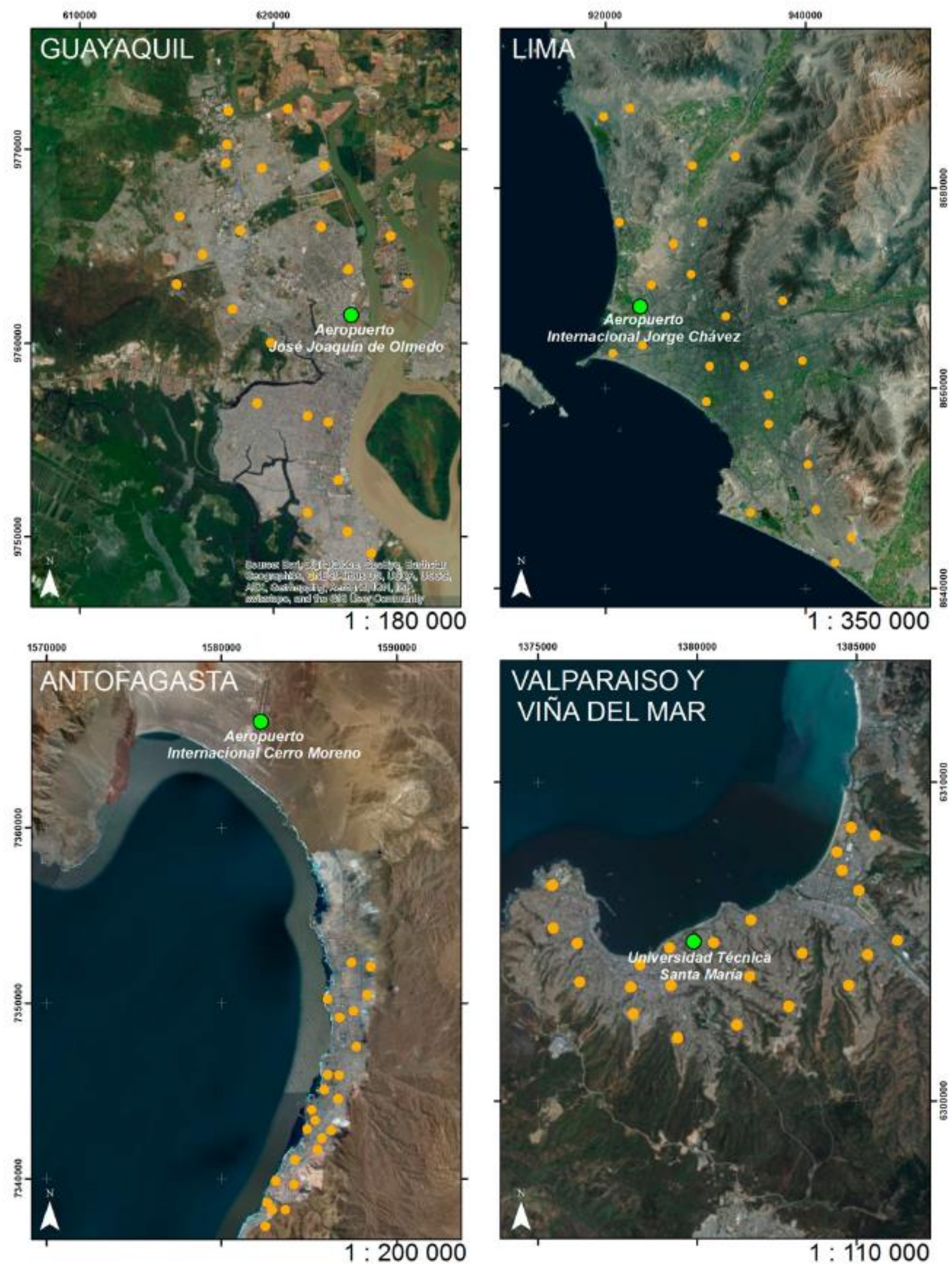

Figure 2 Cities and samples 


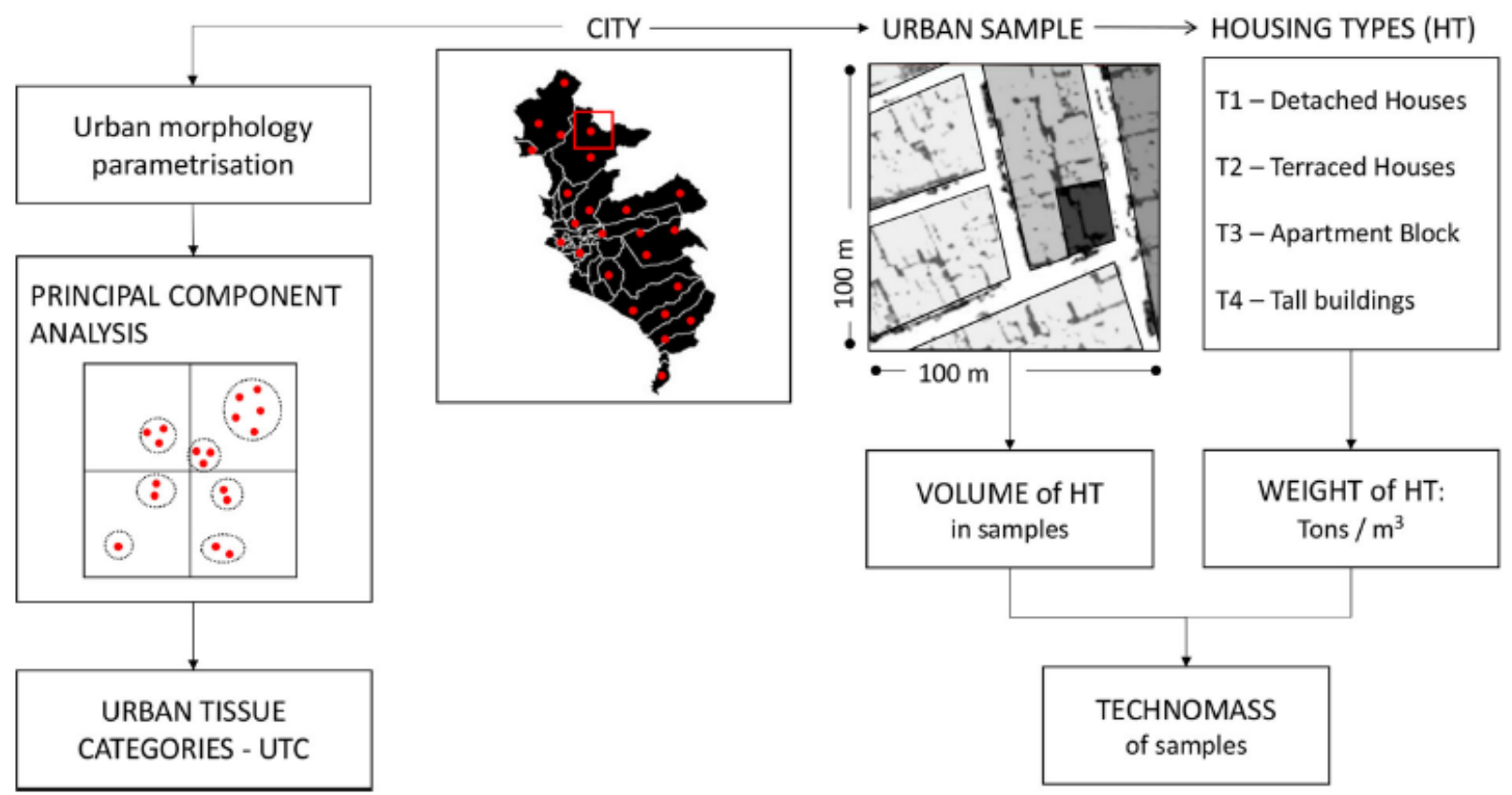

Figure 3 Method for generating urban tissue categories (UTCS) and estimation of technomass. 

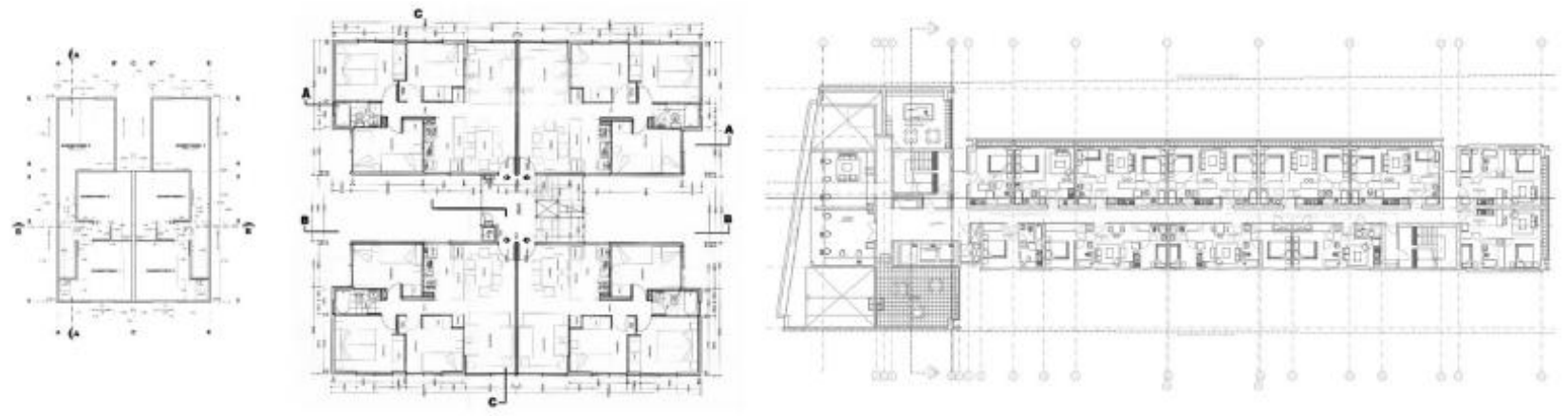

Figure 4 Reference buildings for mass calculation: (1) semi-detached house and row house typologies; (2) apartment building; and (3) tall building. 


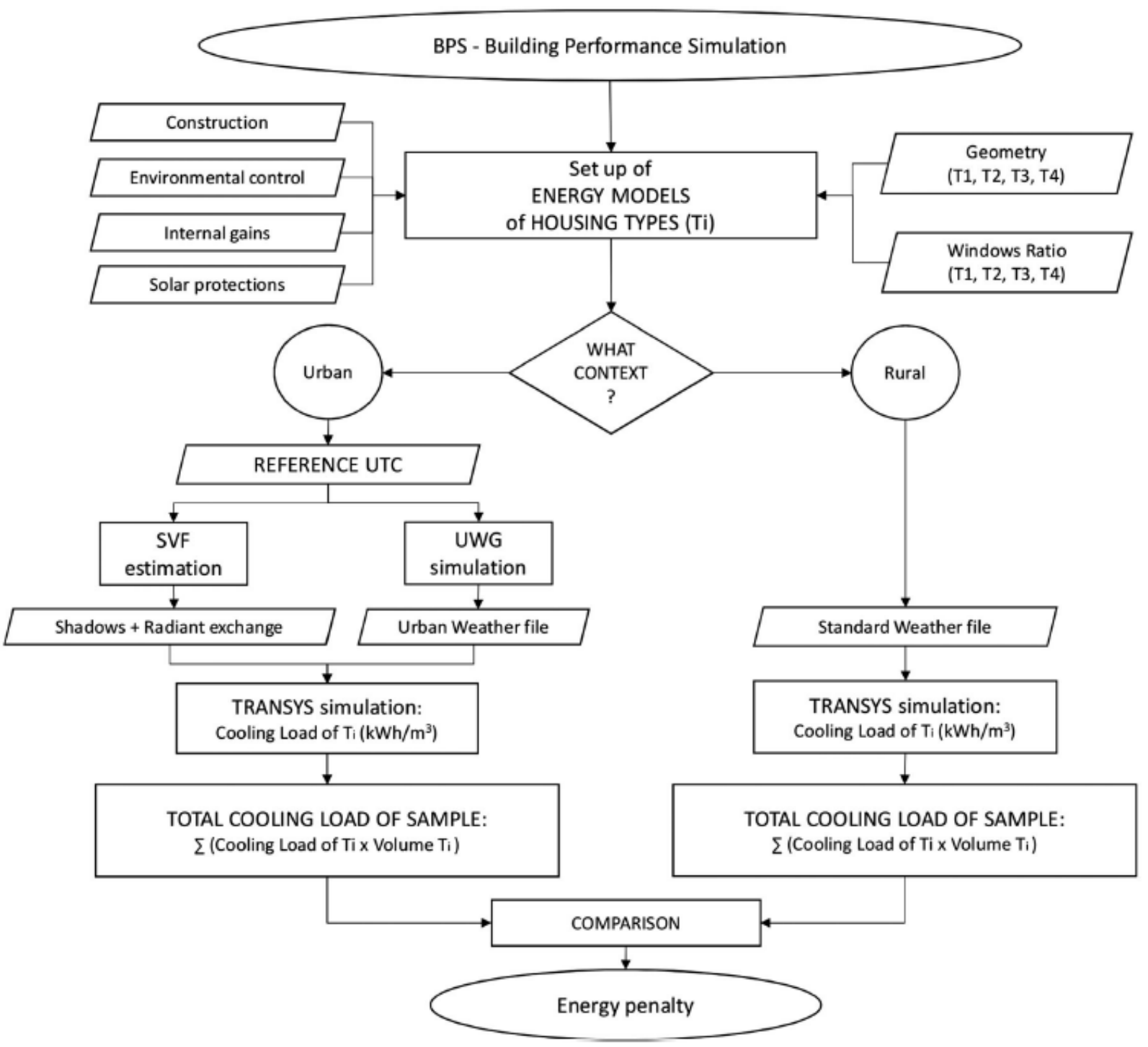

Figure 5 Methodological workflow for simulations. 

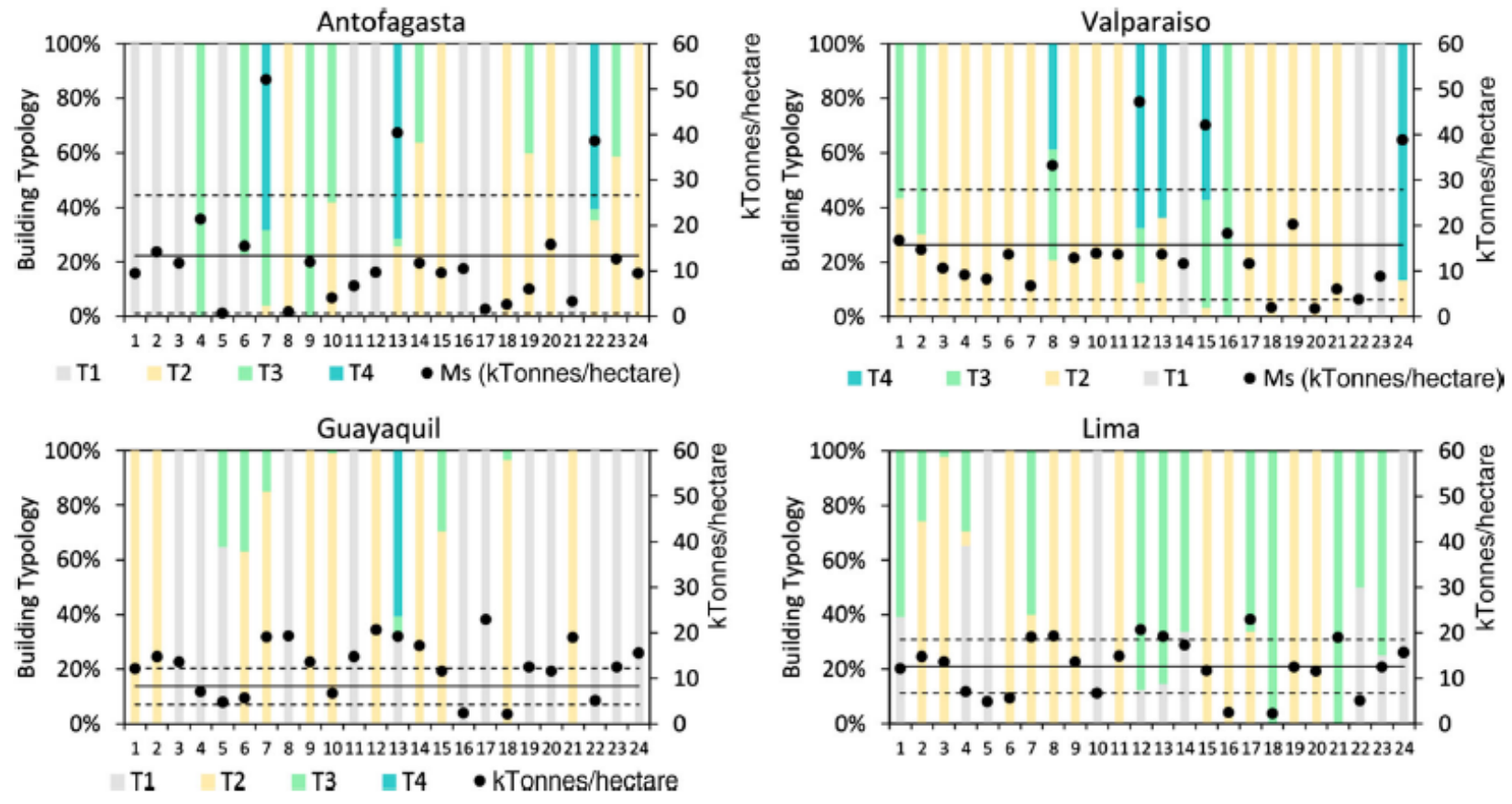

Figure 6 Technomass and building types for each urban sample for the four cities: T1, detached houses; T2, rowhouses; and T3, block. 

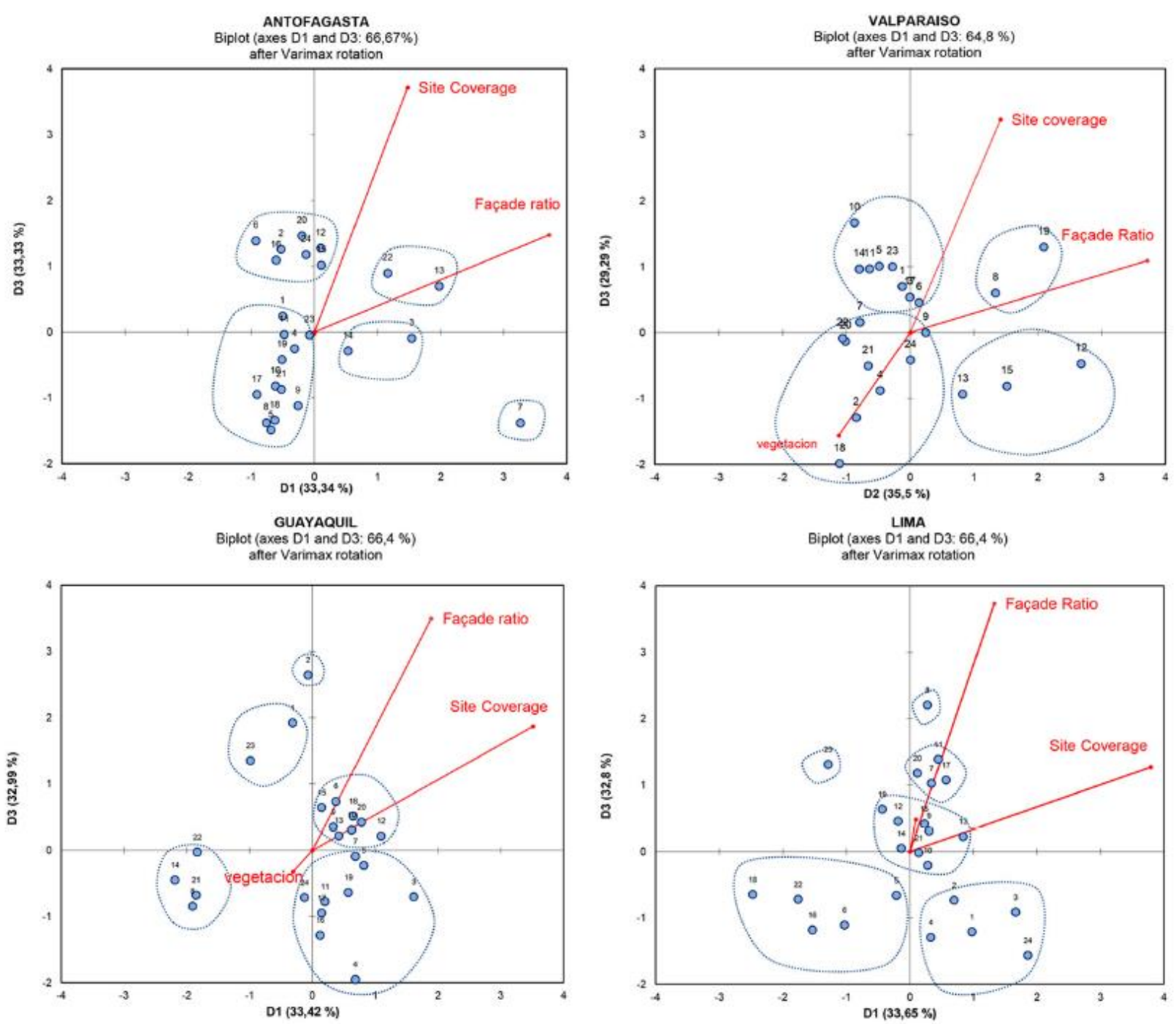

Figure 7 Identification of the clusters of urban samples on the bi-plot graphs resulting from principal component analysis (PCA). Retained components in the bi-plot graph are D1-D3 in the cases of Antofagasta, Lima and Guayaquil, while they are D2-D3 in the case of Valparaíso. 

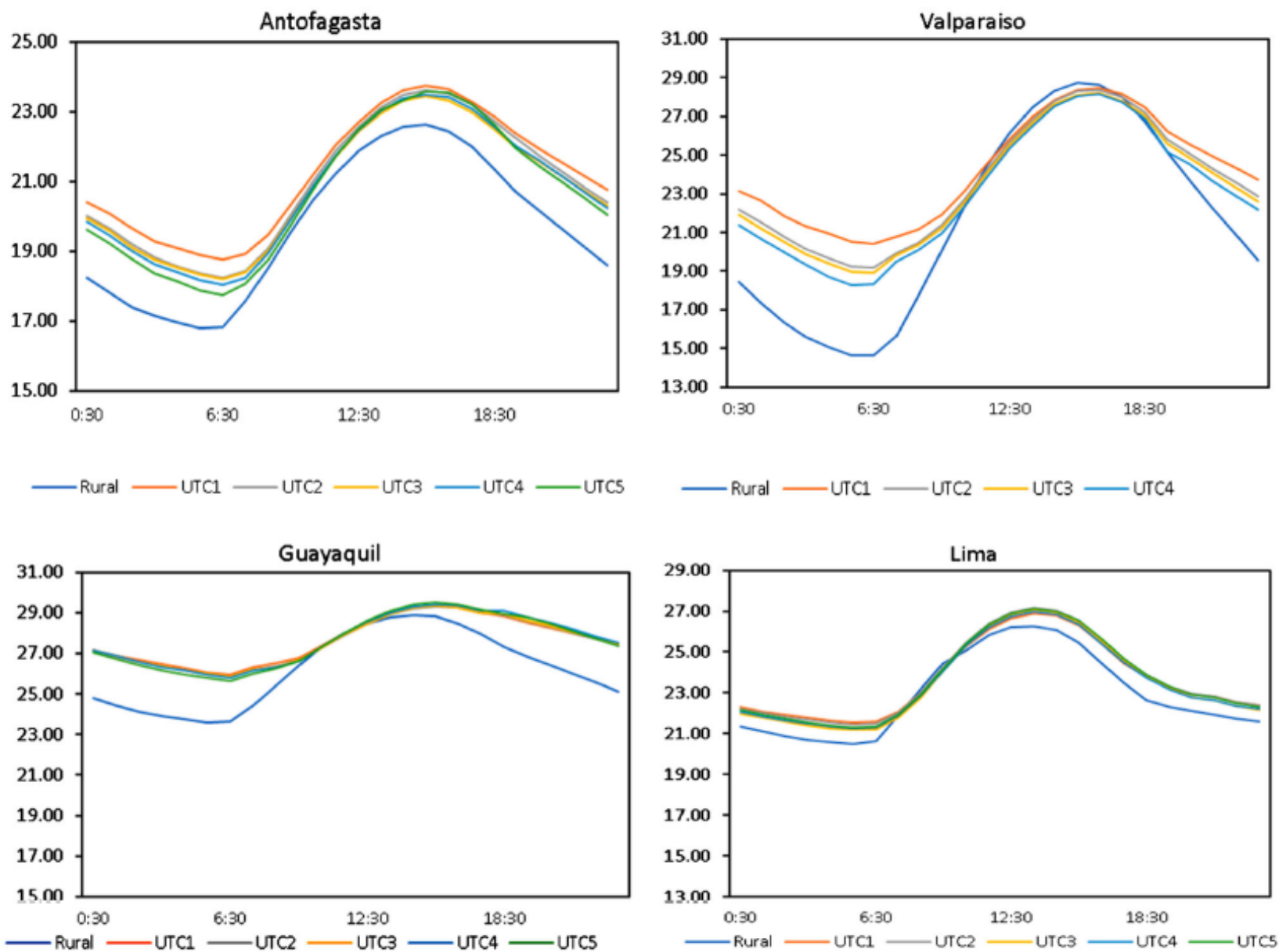

Figure 8 Temperature evolution in the urban tissue category (UTC) for each city in a reference day 


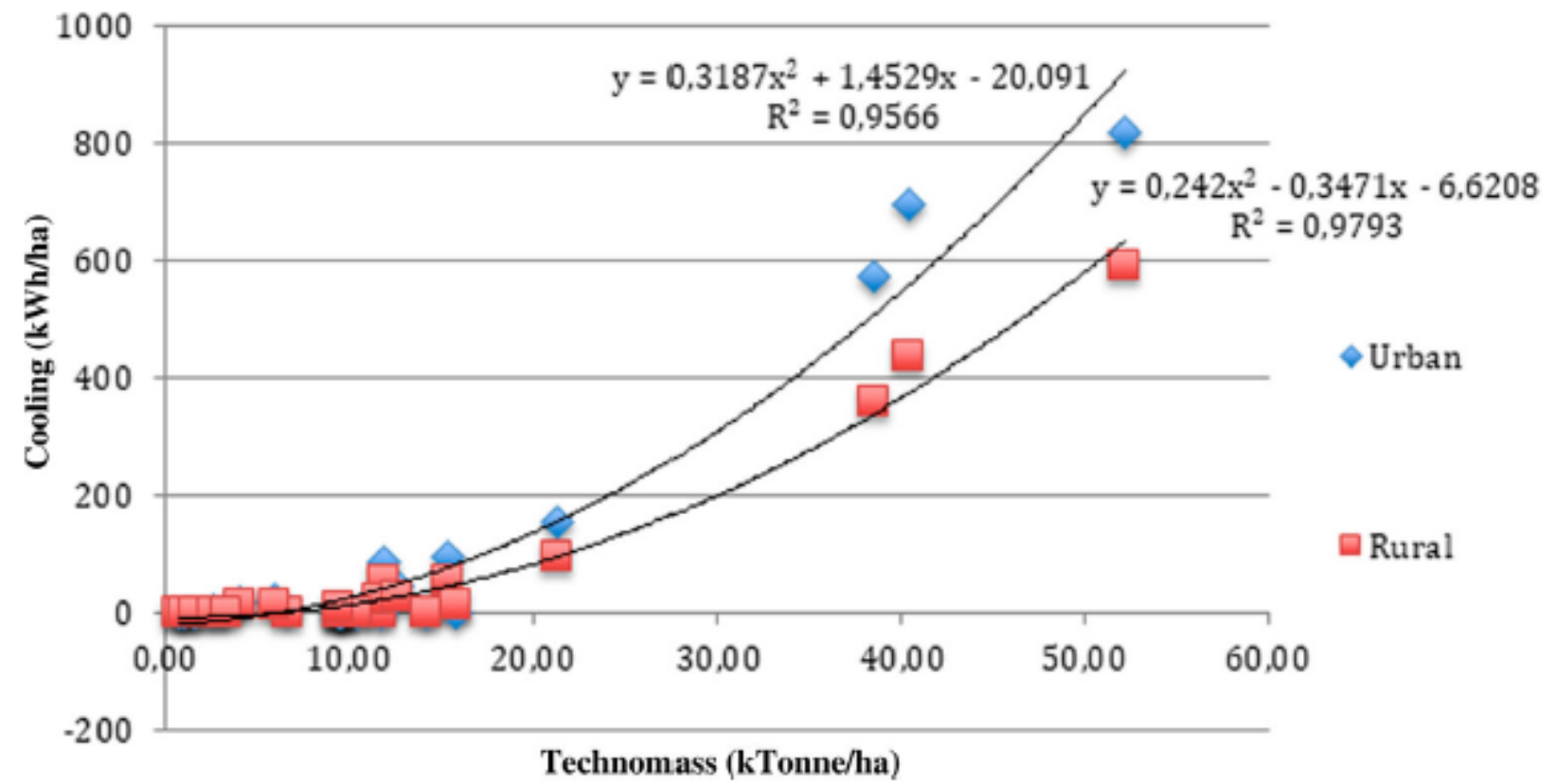

Figure 9 Cooling demand and technomass for Antofagasta samples. 


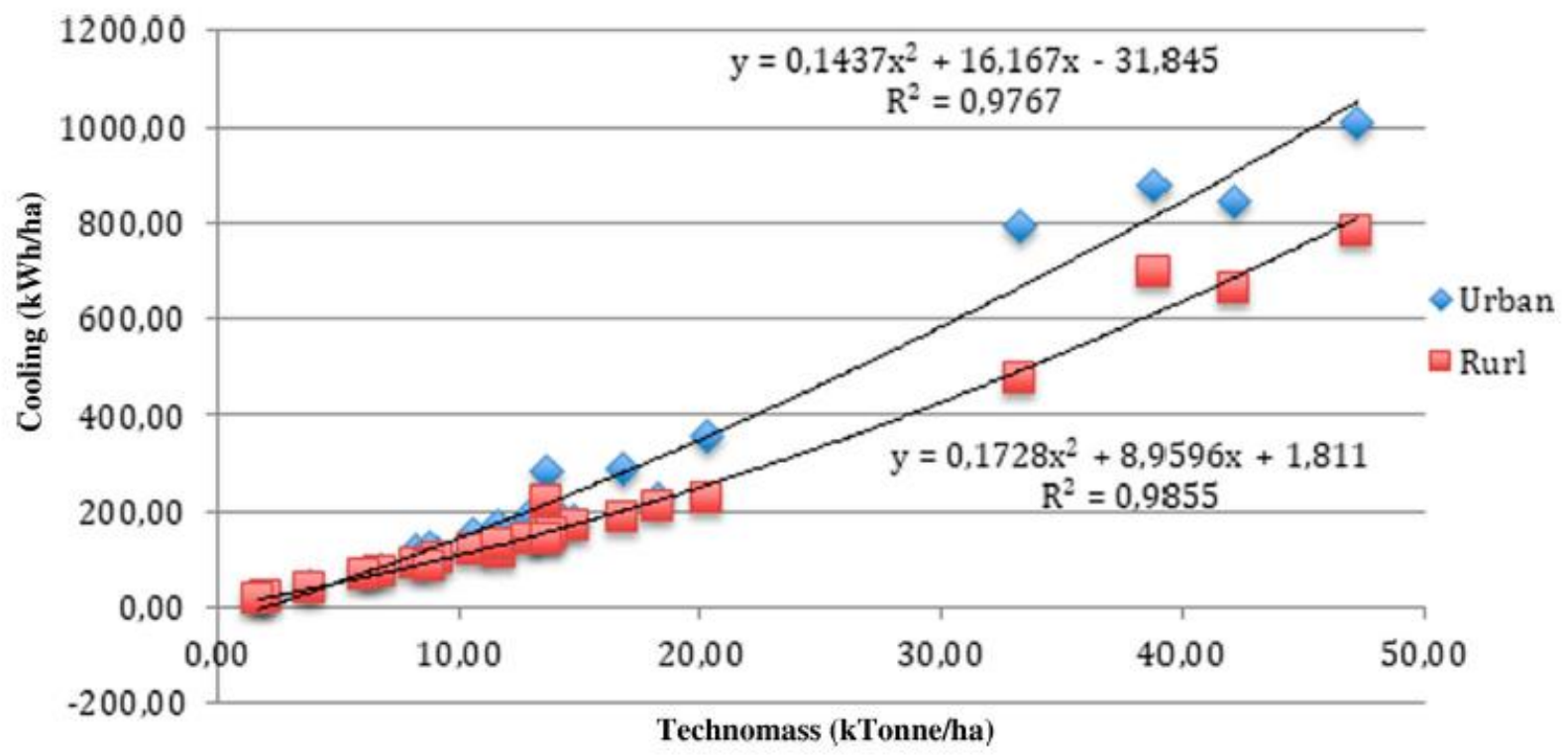

Figure 10 Cooling demand and technomass for Valparaiso samples. 


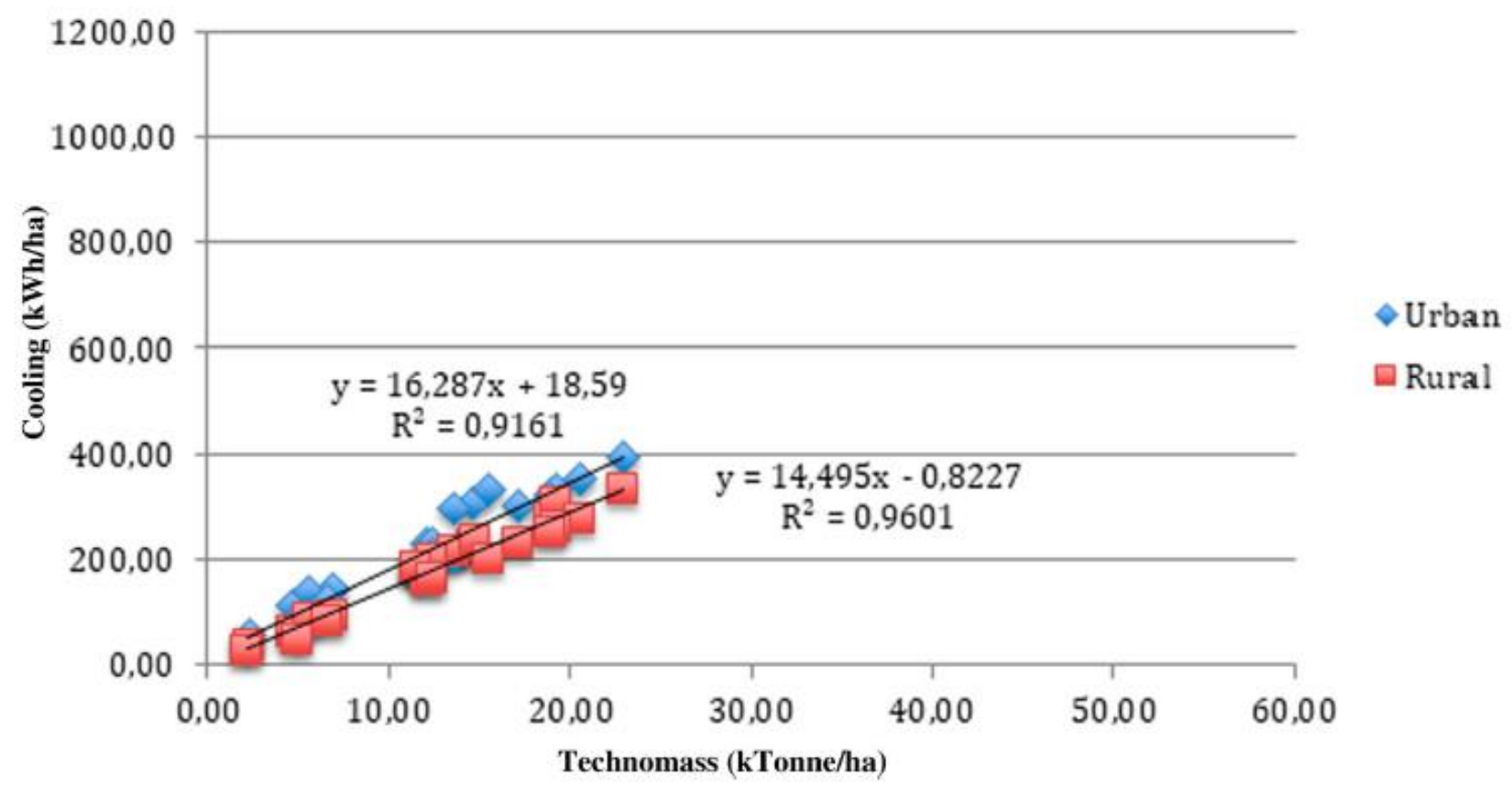

Figure 11 Cooling demand and technomass for Lima samples 


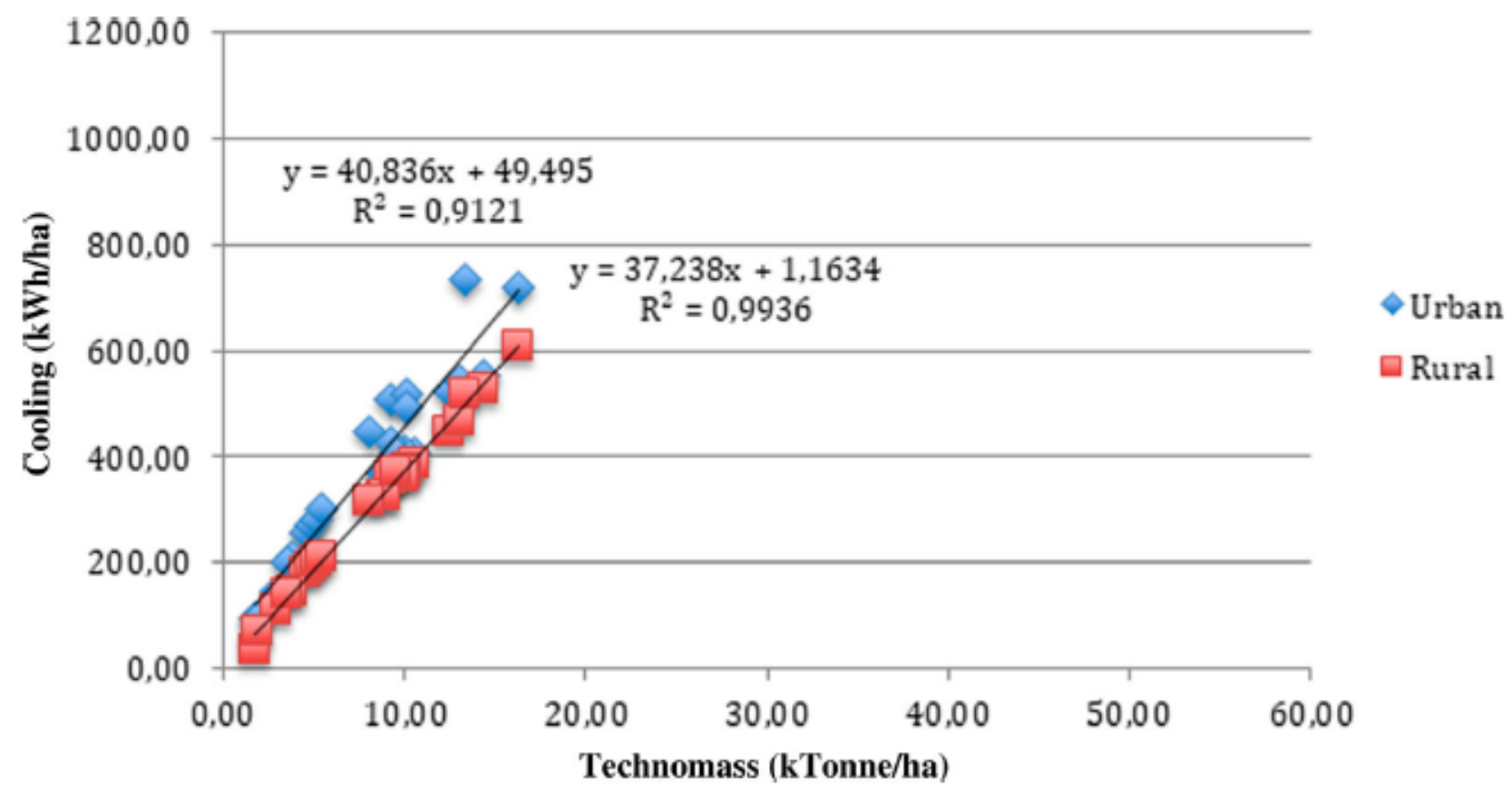

Figure 12 Cooling demand and technomass for Guayaquil samples. 


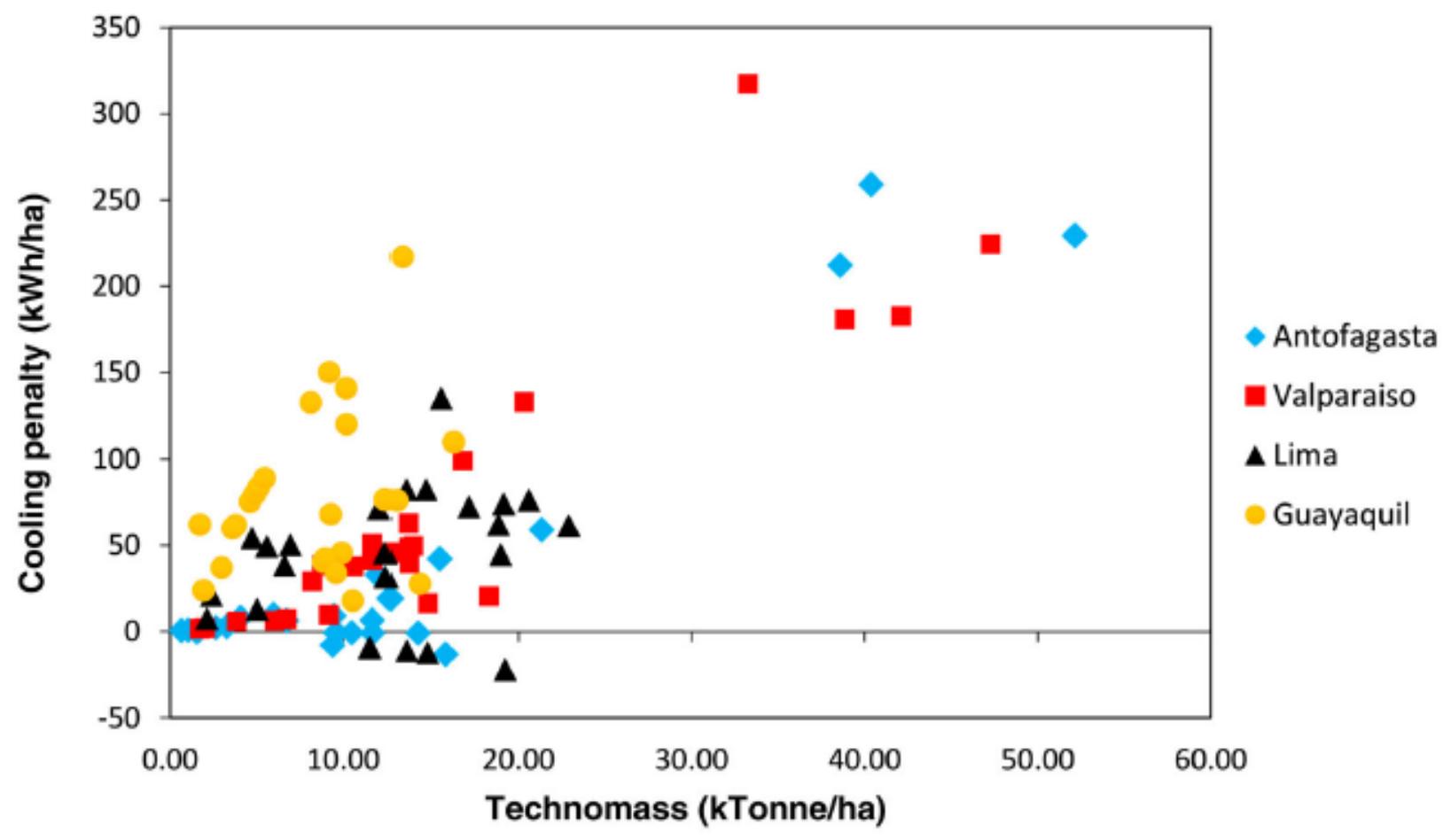

Figure 13 Cooling penalty for each city and sample 


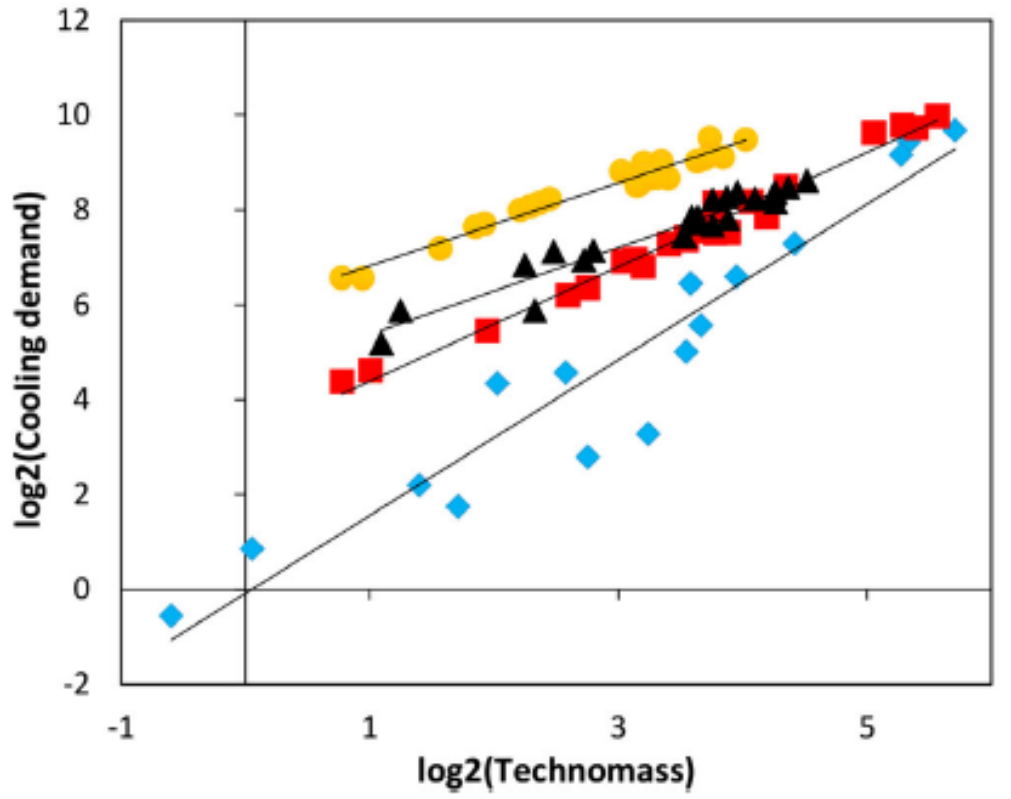

Figure 14 Cooling demand for cities in function of technomass (log scale).
Antofagasta $\quad \begin{gathered}y=1.6406 x-0.0829 \\ R^{2}=0.916\end{gathered}$

Valparaiso $\quad \mathrm{y}=1.2054 \mathrm{x}+3.1819$
$\mathrm{R}^{2}=0.9809$

$\Delta$ Lima

$$
\begin{gathered}
y=0.9155 x+4.4611 \\
R^{2}=0.9232
\end{gathered}
$$

Guayaquil $y=0.8767 x+5.9405$ $R^{2}=0.9599$ 
Table 1 Main characteristics of the four reference cities.

\begin{tabular}{llccc}
\hline & Antofagasta & Valparaiso & Guayaquil & Lima \\
\hline Population & 450,000 & $1,000,000$ & $2,000,000$ & $9,000,000$ \\
Lat & -23 & -23 & -2 & -12 \\
Long & -72 & -71 & -80 & -77 \\
Climate & Cold desert climate & Mediterranean & Tropical wet and dry & Cold desert climate \\
Classification & (BWk) & climate (Csb). & climate (Aw) & (BWk) \\
\hline
\end{tabular}


Table 2: Model set-up for building performance simulation (BPS). Note: Walls are in concrete blocks (150 mm) and mortar $(1 \mathrm{~mm})$; roofs are in light concrete $(100 \mathrm{~mm})$, polystyrene insulation $(50 \mathrm{~mm})$ and asphaltic external mortar $(1 \mathrm{~mm})$; floors are in concrete $(200 \mathrm{~mm})$; and windows are clear single glazed with an aluminium frame and internal shadings (curtains).

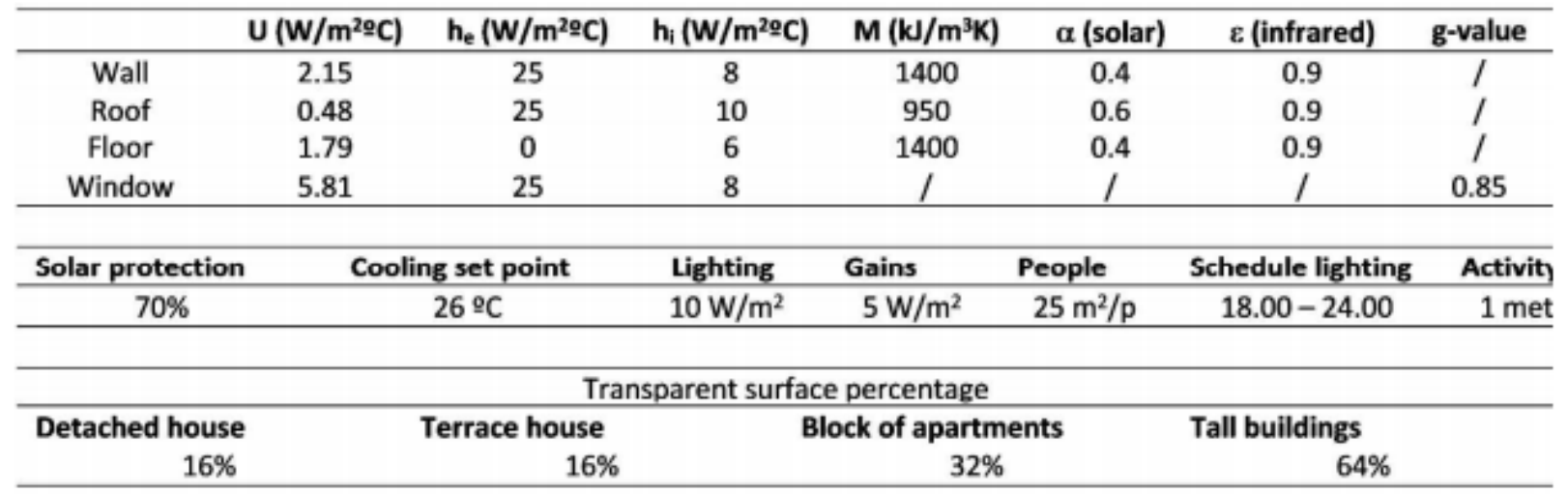


Table 3 Morphological features of each urban tissue category (UTC) for urban heat island (UHI) calculation.

\begin{tabular}{lcccc}
\hline & Coverage Site Ratio & Façade-to-site ratio & Vegetation coverage & Avg Building height \\
Antofagasta & & & & 11.33 \\
\hline UTC1 & 0.76 & 1.65 & $0 \%$ & 4.90 \\
UTC2 & 0.69 & 0.81 & $0 \%$ & 25.70 \\
UTC3 & 0.42 & 2.06 & $2 \%$ & 6.76 \\
UTC4 & 0.49 & 1.19 & $0 \%$ & 7.19 \\
UTC5 & 0.23 & 0.32 & $2 \%$ & 8.36 \\
Valparaiso & & & & 4.92 \\
\hline UTC1 & 0.82 & 1.48 & 0.03 & 14.41 \\
UTC2 & 0.70 & 0.78 & 0.08 & 6.21 \\
UTC3 & 0.49 & 1.24 & 0.27 & 6.00 \\
UTC4 & 0.39 & 0.47 & 0.32 & 5.31 \\
Guayaquil & & & & 5.61 \\
\hline UTC1 & 0.68 & 1.80 & 0.00 & 3.77 \\
UTC2 & 0.59 & 1.03 & 0.07 & 4.40 \\
UTC3 & 0.52 & 1.27 & 0.04 & 0.04 \\
UTC4 & 0.50 & 0.57 & 0.07 & 7.72 \\
UTC5 & 0.17 & 0.16 & & 6.92 \\
Lima & & & 0.13 & 8.49 \\
\hline UTC1 & 0.72 & 1.34 & 0.01 & 7.04 \\
UTC2 & 0.67 & 1.02 & 0.05 & 5.20 \\
UTC3 & 0.38 & 0.91 & 0.13 & 6.38 \\
UTC4 & 0.57 & 0.80 & 0.06 & 0.01 \\
UTC5 & 0.66 & 0.49 & 0.31 & \\
UTC6 & 0.23 & & & \\
\hline
\end{tabular}


Table 4 Average temperature and urban heat island (UHI) intensity during summer season for each city and urban tissue category (UTC).

\begin{tabular}{|c|c|c|c|c|c|c|c|}
\hline & Avg rural T & UTC 1 & UTC 2 & UTC 3 & UTC 4 & UTC5 & UTC6 \\
\hline \multicolumn{8}{|c|}{ Antofagasta } \\
\hline Daily & 19.66 & 1.54 & 1.25 & 1.13 & 1.10 & 0.98 & - \\
\hline Night time & 18.29 & 2.04 & 1.66 & 1.56 & 1.48 & 1.27 & - \\
\hline \multicolumn{8}{|l|}{ Valparaiso } \\
\hline Daily & 21.58 & 2.59 & 1.97 & 1.65 & 1.42 & - & - \\
\hline Night time & 18.65 & 4.33 & 3.38 & 3.00 & 2.62 & - & - \\
\hline \multicolumn{8}{|l|}{ Guayaquil } \\
\hline Daily & 26.18 & 1.47 & 1.41 & 1.44 & 1.48 & 1.42 & - \\
\hline Night time & 24.85 & 2.27 & 2.23 & 2.26 & 2.30 & 2.16 & $=$ \\
\hline \multicolumn{8}{|l|}{ Lima } \\
\hline Daily & 22.94 & 0.72 & 0.77 & 0.60 & 0.60 & 0.72 & 0.60 \\
\hline Night time & 21.29 & 0.94 & 0.90 & 0.68 & 0.72 & 0.82 & 0.59 \\
\hline
\end{tabular}


Table 5 Cooling demand $\left(\mathrm{kWh} / \mathrm{m}^{2}\right)$.

\begin{tabular}{llllllll}
\hline \multicolumn{1}{c}{ Guayaquil } & Rural & UTC1 & UTC2 & UTC3 & UTC4 & UTC5 & UTC6 \\
\hline $\begin{array}{l}\text { Tall building } \\
\text { Block apartment }\end{array}$ & 55.9 & 65.5 & & & & & \\
Detached house & 38.5 & 48.9 & 65.2 & 65.3 & 65.6 & 65.2 & $/$ \\
Terrace house & 36.0 & 41.8 & 48.5 & 48.7 & 49.0 & 48.6 & $/$ \\
\hline \multicolumn{1}{c}{ Lima } & & 45.3 & 41.6 & 54.1 & 54.4 & $/$ \\
Tall building & 35.3 & 37.8 & 40.5 & 37.7 & 48.0 & 48.3 & $/$ \\
Block apartment & 15.3 & 19.8 & & & & & \\
Detached house & 12.5 & 12.4 & 38.2 & 37.2 & 37.2 & 37.8 & 37.2 \\
Terrace house & 15.7 & 14.6 & 20.3 & 19.2 & 19.1 & 19.9 & 19.2 \\
\hline \multicolumn{1}{c}{ Antofagasta } & & 12.8 & 16.6 & 16.5 & 21.0 & 23.7 \\
Tall building & 21.8 & 30.0 & 14.9 & 18.3 & 18.2 & 21.7 & 24.4 \\
Block apartment & 2.7 & 0.9 & & & & & \\
Detached house & 1.1 & 0.1 & 28.4 & 27.7 & 27.5 & 26.9 & $/$ \\
Terrace house & 3.5 & 0.7 & 6.8 & 0.6 & 6.2 & 5.8 & $/$ \\
\hline \multicolumn{1}{c}{ Valparaiso } & & & 1.0 & 0.8 & 2.3 & 7.8 & $/$ \\
Tall building & 28.9 & 43.5 & 2.5 & 2.2 & 4.0 & 11.1 & $/$ \\
Block apartment & 12.8 & 25.0 & & & & & \\
Detached house & 9.6 & 17.1 & 40.0 & 38.0 & 36.7 & $/$ & $/$ \\
Terrace house & 10.9 & 17.3 & 21.5 & 15.2 & 14.1 & $/$ & $/$ \\
\hline
\end{tabular}

